\title{
Persepsi Perubahan Aspek Sosial, Ekonomi, dan Lingkungan Terhadap Keberadaan Jalan Tol Layang AP Pettarani
}

\author{
Lambang Basri Said ${ }^{1}$, Ilham Syafei ${ }^{2}$, Watono ${ }^{3}$, Fadel Muhammad Anis ${ }^{4}$, Muh. Yusuf Al Makassari ${ }^{5}$ \\ 1,2,3,4,5 Program Studi Teknik Sipil Fakultas Teknik Universitas Muslim Indonesia \\ Jl. Urip Sumoharjo KM 05 Makassar, Sulawesi Selatan
}

Email: ${ }^{1}$ lambangbasri.said@umi.ac.id, ${ }^{2}$ Ilham.syafei@umi.ac.id, ${ }^{3}$ Watono.watono@umi.aci.id, ${ }^{4}$ fadelanis39@gmail.com, ${ }^{5}$ muhyusuf7398@gmail.com

\begin{abstract}
Abstrak
Keberadaan Jalan Tol Layang AP Pettarani sebagai bagian dari Jalan Tol Ujung Pandang, sangat diharapkan menjadi salah satu solusi transportasi darat sebagai angkutan logistik penunjang pertumbuhan ekonomi secara nasional, khususnya dalam rangka mengatasi kemacetan serta mendukung mobilitas barang dan jasa di Kota Makassar. Perubahan sosial, ekonomi, dan lingkungan tersebut merupakan pengaruh yang ditimbulkan atau kemungkinan besar akan terjadi, yang menyangkut keadaan sosial, ekonomi, dan lingkungan masyarakat pengguna jalan. Penelitian ini bertujuan untuk menganalisis seberapa besar persepsi perubahan aspek sosial, ekonomi, dan lingkungan masyarakat pengguna jalan terhadap keberadaan jalan tol layang AP Pettarani. Jenis data yang digunakan dalam penelitian ini adalah data subyek. Data kuesioner yang digunakan adalah dari hasil jawaban responden atas pertanyaan yang diajukan penulis kepada responden dalam bentuk tulisan. Adapun untuk mengetahui hubungan variabel-variabel yang mempunyai hubungan, maka dilakukan pengujian hipotesis dengan perhitungan statistik. Untuk penganalisisan data digunakan SPSS versi 21.00 dalam model dan pengkajian hipotesis. Berdasarkan dari hasil kuesioner maka didapatkan variabel-variabel mana saja yang mempunyai pengaruh signifikan terhadap keberadaan jalan tol layang AP Pettarani.
\end{abstract}

Kata Kunci

Jalan Tol Layang;

Perubahaan;

Sosial; Ekonomi;

Lingkungan.

\begin{abstract}
The existence of the AP Pettarani Flyover Toll Road as part of the Ujung Pandang Toll Road, is expected to be one of the land transportation solutions as a logistical transportation to support national economic growth, especially in the context of overcoming congestion and supporting the mobility of goods and services in Makassar City. These social, economic, and

Keywords

Flyway; Changes;

Social; Economy;

Environment. environmental changes are the effects that are caused or will most likely occur, which involve the social, economic, and environmental conditions of road user communities. This study aims to analyze how much the perception of changes in social, economic, and environmental aspects of the road user community to the existence of the AP Pettarani flyover. The type of data used in this study is subject data. Questionnaire data used are the results of respondents' answers to questions raised by the author to respondents in written form. As for knowing the relationship of the variables that have a relationship, then testing the hypothesis with statistical calculations. For analyzing data SPSS version 21.00 is used in the model and hypothesis assessment. Based on the results of the questionnaire, it is obtained which variables have a significant influence on the existence of the AP Pettarani flyover.
\end{abstract}

\section{PENDAHULUAN}

Keberadaan Jalan Tol Layang AP Pettarani sebagai bagian dari Jalan Tol Ujung Pandang, sangat diharapkan menjadi salah satu solusi transportasi darat sebagai angkutan logistik penunjang pertumbuhan ekonomi secara nasional, khususnya dalam rangka mengatasi kemacetan serta mendukung mobilitas barang dan jasa di Kota Makassar. Tujuan pembangunan Jalan Tol Layang AP Pettarani adalah untuk memperlancar lalu lintas di daerah yang telah berkembang, meningkatkan pelayanan distribusi barang dan jasa guna menunjang pertumbuhan ekonomi, dan meningkatkan pemerataan hasil pembangunan dan keadilan. Jaringan jalan merupakan salah satu faktor pendukung keberhasilan suatu pembangunan karena jalan berperan untuk pemindahan barang dan manusia sehingga diperlukan jaringan jalan yang memadai. Jalan tol merupakan jalan alternatif untuk mempercepat sarana transportasi, perkembangan industri pariwisata, menunjang pertumbuhan dan percepatan proses ekonomi yang kerap terhambat karena kendala transportasi, mengurangi kemacetan 
akibat pasar tumpah, pasar tradisional, penyempitan jalan, jembatan rusak, jalan yang berlubang dan lain -lain adalah hal yang menghambat proses ekonomi secara merata dan cepat.

Sebelum diselenggarakannya pembangunan Jalan Tol Layang AP Pettarani, dalam beberapa tahun terakhir masyarakat kota Makassar yang melintas di Jalan AP Pettarani banyak mengeluhkan kondisi jalan tersebut dikarenakan pada jam puncak mengalami kemacetan dan sangat mengganggu arus lalu lintas pada saat mereka melintas dan menyebabkan terbuangnya waktu yang lama dalam berkendara dan terganggunya distribusi barang dan jasa (Sari \& Kisman, 2021) (Watono dkk, 2020). Seiring dengan bertambah pesatnya pertumbuhan jumlah kendaraan pada kota Makassar tiap tahun, mengakibatkan meningkatnya volume lalu lintas pada jalan AP Pettarani. Maka dari itu solusi untuk mengurai kemacetan pada jalan tersebut dilakukan pembangunan jalan tol layang (Pangaribuan 2005) (Pangaribuan 2014). Dengan adanya jalan tol layang AP Pettarani sepanjang 4,3 km tersebut akan merubah aspek sosial, ekonomi dan lingkungan pada masyarakat pengguna jalan yang sering mengakses jalan AP Pettarani tersebut. Perubahan sosial, ekonomi, dan lingkungan tersebut merupakan pengaruh yang ditimbulkan atau kemungkinan besar akan terjadi yang menyangkut keadaan sosial ekonomi dan lingkungan masyarakat pengguna jalan (Pratiwi, \& Hardini 2016) (Humang \& Amrin, 2018).

Perubahan yang timbul akibat keberadaan jalan tol layang dari aspek sosial peneliti tinjau yaitu seberapa besar perubahan aktifitas sehari - hari, kemudahan pergerakan berkendara, waktu tempuh dari tempat asal ke tempat tujuan masyarakat pengguna jalan dan adapun juga yang kami teliti yaitu faktor psikis masyarakat pengguna jalan yang akan berpengaruh yaitu dari tingkat stress, tingkat kelelahan dan tingkat kesehatan di jalan.

Kemudian perubahan yang timbul dari keberadaan jalan tol layang dari aspek ekonomi yaitu fungsi jalan tol layang AP. Pettarani sebagai salah satu solusi mengatasi kemacetan yang ada di jalan AP. Pettarani akan mempengaruhi pengguna Bahan Bakar Minyak (BBM) dan biaya perawatan kendaraan seperti (spare part, biaya ganti oli dan lain - lain) yang disebabkan oleh penggunaan BBM yang lebih efisien dan performa mesin kendaraan yang bekerja secara optimal. Fungsi jalan tol layang AP. Pettarani juga akan mempengaruhi waktu tempuh masyarakat pengguna jalan yang disebabkan oleh biaya tidak terduga dari waktu yang terbuang di jalan dan mempengaruhi ekonomi masyarakat yang bisa saja di sebabkan karena kemudahan distribusi barang dan lain - lain (Arrang 2016). Dan apabila jalan tol layang AP Pettarani menjadi salah satu cara masyarakat pengguna jalan untuk menghindari kemacetan maka ada biaya tambahan sehari - hari masyarakat karena biaya tol untuk melintasi jalan tol layang tersebut.

Sedangkan perubahan yang timbul dari keberadaan jalan tol layang dari aspek lingkungan yaitu adanya jalan tol layang AP. Pettarani sebagai solusi mengatasi kemacetan yang ada di jalan AP. Pettarani akan mempengaruhi tingkat kenyamanan berlalu - lintas masyarakat pengguna jalan, dan mempengaruhi polusi udara dari kendaraan yang disebabkan oleh laju kendaraan yang meningkat dan tidak mengalami keadaan berhenti di jalan yang akan mengurangi polusi udara yang disebabkan oleh mesin kendaraan yang berjalan secara optimal, adapun fungsi jalan tol layang akan mempengaruhi polusi udara dari debu yang dibawa oleh kendaraan berat pembawa material seperti truk pasir, truk pengangkut semen dan lain - lain yang sering melewati Jalan AP. Pettarani yang disebabkan oleh bertambahnya jalur untuk truk yang wajib melalui jalan tol layang untuk menghindari pengaruh polusi udara dari muatan yang di bawa maupun meningkatkan laju kendaraan truk menuju ke tempat tujuan, adanya Jalan Tol Layang AP Pettarani juga akan mempengaruhi masalah terhadap lingkungan lalu lintas yang ada yaitu kebisingan dan getaran. kebisingan biasanya berasal dari hasil suara kendaraan terutama dari suara knalpot, suara mesin kendaraan maupun interaksi roda dan kendaraan yang di sebabkan oleh kendaraan berat (truk dan bus) dan mobil penumpang (Fisu, 2019). Getaran sendiri juga di sebabkan oleh padatnya kendaraan berat (truk dan bus) dan mobil penumpang melewati jalan tersebut. Dan bertambahnya jalur yang di lalui oleh kendaraan berat (truk dan bus) dan mobil penumpang yang disebabkan oleh keberadaan jalan tol layang AP. Pettarani akan mempengaruhi masyarakat pengguna jalan yang akan melewati jalan AP. Pettarani (Said dkk 2017) (Said \& Ilham 2019). Dan diketahui juga imbas dari keberadaan jalan tol layang AP Pettarani membuat 1.012 pohon ditebang dan akan mempengaruhi tingkat kenyamanan berkendara masyarakat pengguna jalan karena fungsi pohon untuk menyerap polusi kendaraan maupun debu juga bisa menghalagi pancaran sinar matahari langsung terhadap masyarakat pengguna jalan yang melintasi jalan AP Pettarani.

Sehubung dengan permasalahan diatas, maka diperlukan analisa untuk mengetahui perubahan sosial, ekonomi dan lingkungan sehingga dapat dicari solusi dari permasalahan tersebut.

Penelitian ini dimaksud untuk melakukan studi persepsi perubahan aspek sosial, ekonomi dan lingkungan masyarakat pengguna jalan terhadap keberadaan jalan tol layang AP Pettarani, adapun tujuan dari penelitian ini adalah (1) Menganalisis seberapa besar persepsi perubahan aspek sosial masyarakat pengguna jalan terhadap keberadaan jalan tol layang AP Pettarani, (2) Menganalisis seberapa besar persepsi perubahan aspek 
ekonomi masyarakat pengguna jalan terhadap keberadaan jalan tol layang AP Pettarani dan (3) Menganalisis seberapa besar persepsi perubahan aspek lingkungan masyarakat pengguna jalan terhadap keberadaan jalan tol layang AP Pettarani.

\section{METODE PENELITIAN}

\subsection{Lokasi Penelitian}

Adapun lokasi penelitian adalah di Kota Makassar tepatnya di Jalan AP Pettarani dimana berbagai tipe masyarakat mulai dari pelajar, mahasiswa, pegawai negeri sipil, karyawan swasta, pedagang, penduduk sekitar dan sebagainya, melintasi jalan tersebut. Selain itu, lokasi Jalan AP Pettarani banyak pula perkantoran dan pusat perdagangan yang berada disisi jalan tersebut.

\subsection{Variabel Penelitian}

Variabel dalam penelitian ini terbagi atas 2 variabel yaitu :

1. Variabel bebas yaitu variabel yang menjadi penyebab atau memengaruhi, meliputi faktor-faktor yang di ukur, dimanipulasi atau dipilih oleh peneliti dan variabel bebas dalam penelitian tersebut adalah pada aspek sosial (X1) yaitu keberadaan jalan tol layang AP Pettarani yang mempengaruhi perubahan aktifitas sehari - hari, kemudahan pergerakan berkendara, waktu tempuh dari tempat asal ke tempat tujuan masyarakat pengguna jalan dan adapun juga yang kami teliti yaitu faktor psikis masyarakat dan pengguna jalan yang akan berpengaruh yaitu dari tingkat stress, tingkat kelelahan dan tingkat kesehatan di jalan (Silondae dkk, 2016), pada aspek ekonomi (X2) yaitu di lihat dari seberapa besar pengaruh keberadaan jalan tol layang AP Pettarani terhadap ekonomi masyarakat, biaya bahan bakar minyak (BBM), biaya perawatan kendaraan (biaya spare part, ganti oli dan lain-lain) (Meidianisa 2016), biaya yang di sebabkan waktu tempuh di jalan dan biaya tambahan (biaya tol) terhadap kehidupan sehari - hari masyarakat pengguna jalan sedangkan aspek lingkungan (X3) yaitu di lihat dari seberapa besar pengaruh tingkat kenyamanan berlalu - lintas (Hidayat dkk, 2017), tingkat polusi udara (dari asap kendaraan dan debu), tingkat kebisingan, getaran dan tingkat kenyamanan berkendara yang di sebabkan pemotongan pohon masyarakat pengguna jalan (Ismadaryani 2012) (Boediningsih 2017).

2. Variabel Terikat yaitu faktor - faktor yang di amati dan di ukur dalam rangka menentukan pengaruh variabel bebas, di dalamnya itu termaksud faktor yang muncul, atau tidak muncul, atau berubah sesuai dengan yang di perkenankan oleh peneliti dan variabel terikat dalam penelitian tersebut adalah Keberadaaan Jalan Tol Layang AP Pettarani (Y).

\subsection{Ukuran Sampel}

Menurut Sugiyono (2010) sampel adalah bagian dari jumlah dan karakteristik yang dimiliki oleh populasi. Bila populasi besar, dan peneliti tidak mungkin mempelajari semua yang ada pada populasi, misalnya karena keterbatasan dana, tenaga dan waktu, maka peneliti dapat menggunakan sampel yang diambil dari populasi itu Roscoe (1982) memberikan saran-saran tentang ukuran sampel untuk penelitian seperti berikut ini.

a. Pada setiap penelitian, ukuran sampel yang layak berkisar antara 30 sampai dengan 500 .

b. Bila sampel dibagi dalam kategori (misalnya : pria-wanita, pegawai negeri-swasta dan lain-lain) maka jumlah anggota sampel setiap kategori minimal 30.

adapun juga metode yang di gunakan dalam penentuan seberapa besar sampel atau responden yang di gunakan yaitu Rumus Slovin adalah sebagai berikut :

Keterangan :

$$
n=\frac{N}{1+N(e)^{2}}
$$

$\mathrm{n}=$ Ukuran sampel / jumlah responden

$\mathrm{N}=$ Ukuran Populasi

$\mathrm{E}=$ Presentase kelonggaran ketelitian kesalahan pengambilan sampel yang masih bisa di tolerir, $\mathrm{e}=0,1$

Dalam rumus slovin ada ketentuan sebagai berikut :

1. Nilai e $=0,1(10 \%)$ untuk populasi dalam jumlah besar

2. Nilai $\mathrm{e}=0,2(20 \%)$ untuk populasi dalam jumlah kecil

Jumlah populasi dalam peneitian ini terbagi atas 2 yaitu pengguna motor dan pengguna mobil ( roda 4 ) di dapatkan dari hasil survei LHR (lalu lintas harian rata-rata) di ruas jalan AP Pettarani, dan di dapatkan LHR (lalu lintas harian rata-rata) dari data skripsi yang berjudul "(penilaian indikator tentang transportasi berkelanjutan kawasan perkotaan studi kasus ruas jalan AP Pettarani. Aswar arifin dan Agung setiawan, 2018)" di dapatkan jumlah pengguna motor yang melewati Jalan AP. Pettarani selama 12 jam dari arah utara dan 
selatan yaitu : 247146 dan pengguna mobil dari arah utara dan selatan yaitu : 46136 maka di total pengguna kendaraan yang melewati jalan AP Pettarani adalah $247146+46136=293282$ kendaraan maka untuk mengetahui sampel penelitian dengan perhitungan sebagai berikut :

$$
\begin{aligned}
& n=\frac{293282}{1+293282(0,1)^{2}} \\
& n=\frac{293282}{2933,82} \\
& n=99,97 \text { disesuaikan oleh peneliti menjadi minimal } 100 \text { responden }
\end{aligned}
$$

Maka pada penelitian ini keseluruhan populasi sampel adalah minimal 100 responden yang merupakan pengendara mobil dan motor yang melewati jalan AP Pettarani.

\subsection{Jenis dan Sumber Data}

1. Data Primer yaitu data yang diperoleh secara langsung dari sumbernya, diamati, dan dicatat untuk pertama kalinya. Dalam penelitian ini yang dimaksud data primer adalah data yang berasal dari responden. Data ini diperoleh dari hasil kuesioner dalam isi kuesioner kita akan mendapatkan data seperti berikut : identitas responden, aspek umum responden seperti tingkat pendidikan pekerjaan di tekuni dan lain - lian, dan pada aspek sosial data yang di dapatkan yaitu perubahan aktifitas sehari hari, kemudahan pergerakan berkendara, waktu tempuh dari tempat asal ke tempat tujuan, tingkat stress, tingkat kelelahan dan tingkat kesehatan di jalan, pada aspek ekonomi data yang di dapatkan yaitu pengaruh ekonomi masyarakat, biaya bahan bakar minyak (BBM), biaya perawatan kendaraan (biaya spare part, ganti oli dan lain-lain), biaya yang di sebabkan waktu tempuh di jalan dan biaya tambahan (biaya tol) terhadap kehidupan sehari - hari, pada aspek lingkungan data yang di dapatkan yaitu pengaruh tingkat kenyamanan berlalu - lintas, tingkat polusi udara (dari asap kendaraan dan debu), tingkat kebisingan, getaran dan tingkat kenyamanan berkendara yang di sebakan pemotongan pohon masyarakat pengguna jalan.

2. Data Sekunder yaitu data yang diperoleh dengan menggunakan metode dokumentasi yaitu pengambilan data dari buku, surat kabar, majalah yang relevan dengan penelitian.Data sekunder seperti berikut : Peta jaringan Jalan,Letak Geografis penelitian, jumlah pengguna motor dan mobil (roda 4) dari hasil survei LHR (lalu lintas harian rata-rata) di ruas jalan AP Pettarani.

\subsection{Jenis Penelitian}

Pendekatan yang digunakan dalam penelitian ini adalah kuantitatif deskriptif yang berfokus pada pembahasan atas rumusan masalah. Penelitian deskriptif dapat menggambarkan suatu gejala sosial atau dapat dikatakan mampu menggambarkan sesuatu yang tengah terjadi pada saat penelitian ini berlangsung. Pembahasan dalam penelitian ini merupakan hasil pengolahan data-data yang digunakan dan didasarkan pada variabel-variabel yang dapat dijelaskan secara terukur.

\subsection{Metode Pengumpulan Data}

Metode pengumpulan data merupakan salah satu aspek yang berperan dalam kelancaran dan keberhasilan dalam suatu penelitian. Dalam penelitian ini metode pengumpulan data yang digunakan adalah kuesioner. Kuesioner adalah teknik pengumpulan data melalui formulir-formulir yang berisi pertanyaan-pertanyaan yang diajukan secara tertulis pada seseorang atau sekumpulan orang untuk mendapatkan jawaban atau tanggapan dan informasi yang diperlukan oleh peneliti. Dalam pengumpulan data denga cara membagikan kuesioner kita mengambil responden dari orang - orang yang selalu beraktivitas di sebelah kiri - kanan dari jalan AP Pettarani contoh titik - titik lokasi pengambilan data kita ambil di Kantor - kantor pemerintah, perkantoran Swasta dan lain - lain sebagai tempat pengambilan data dan tidak menutup kemungkinan dalam pengambilan responden bisa saja kita mengambil dari orang - orang yang tidak beraktivitas di sepanjang kiri dan kanan Jalan AP Pettarani tetapi selalu melewati Jalan AP Pettarani dalam beraktivitas dan dalam menentukan responden ini kita menggunakan sistem wawancara sebelum membagikan kuesioner dengan menanyakan asal dan menuju kemana, dan berapa sering mereka melewati jalan AP Pettarani dalam setiap beraktivitasnya.

\subsection{Metode Analisis}

\section{Analisis Kualitatif Deskriptif}

Metode ini menjabarkan hasil dari penggunaan metode-metode yang digunakan sehingga menjadi jelas maksudnya. Selain itu juga digunakan untuk menerangkan data-data yang membutuhkan 
penjabaran dan penjelasan. Penekanan analisis ini pada ketajaman dan kepekaan berpikir dan menganalisa suatu masalah atau kecenderungan yang terjadi di lapangan.

2. Analisis Kuantitatif

Adapun untuk mengetahui hubungan variabel-variabel yang mempunyai hubungan, maka dilakukan pengujian hipotesis dengan perhitungan statistik. Untuk penganalisisan data digunakan SPSS versi 21.00 dalam model dan pengkajian hipotesis.

\subsection{Waktu Penelitian}

Dalam kasus disebutkan pengertian survey yaitu tindakan mengukur atau memperkirakan. Namun dalam penelitian servey lebih berarti sebagai suatu cara melakukan pengamatan di mana indicator mengenai variabel adalah jawaban - jawaban terhadap pertanyaan yang di berikan kepada responden baik secara lisan maupun tertulis. Servey biasanya dilakukan satu kali. Peneliti tidak berusaha untuk mengatur atau mengusai situasi. Jadi perubahan dalam variabel adalah hasil dari peristiwa yang terjadi dengan sendirinya.

Penelitian dilaksanakan selama 1 bulan dengan hari yang telah di tentukan berdasarkan kondisi dilapangan. Pengambilan data di lakukan pada hari Senin, Selasa, Rabu, Kamis, dan Jum'at.

\section{HASIL DAN PEMBAHASAN}

\subsection{Hasil Uji Kualitas Data}

\subsubsection{Hasil Uji Validitas}

Menurut Sugiono (2008:363), validitas adalah suatu ukuran yang menunjukkan kevalidan atau kesahihan suatu instrument. Pengujian validitas mengacu pada sejauhmana instrumen dalam menjalankan fungsinya. Suatu instrumen dikatakan valid jika instrumen tersebut dapat digunakan untuk mengukur apa yang akan diukur. Hasil uji validitas yang diperoleh dalam penelitian dengan menggunakan aplikasi SPSS ver. 21 adalah sebagai berikut. Berdasarkan tabel hasil uji validasi menunjukkan bahwa nilai koefisien korelasi $r$ hitung $>$ dari nilia $r$ tabel dan tingkat signifikansi $0,000<0,05$ untuk semua item pertanyaan, sehingga dapat disimpulkan bahwa instrument yang digunakan memiliki kevalidan.

\subsubsection{Hasil Uji Reliabilitas}

Uji reliabilitas digunakan untuk mengukur konsistensi konstruk/variabel penelitian. Suatu variabel dikatakan reliable (handal) jika jawaban responden terhadap pertanyaan konsisten atau stabil dari waktu ke waktu. Tingkat reliabilitas suatu konstruk/variabel penelitian dapat dilihat dari hasil statistik Cronbach Alpha $(\alpha)$. Suatu variabel dikatakan reliable jika memberikan nilai cronbach alpha $>0,60$ (Ghozali, 2005). Hasil uji reliabilitas yang diperoleh dalam penelitian dengan menggunakan aplikasi SPSS ver. 21 adalah sebagai berikut. Berdasarkan tabel hasil uji reliabilitas menunjukkan nilai Cronbach's Alpha 0,770 >0,60, sehingga dapat disimpulankan bahwa variabel yang digunakan reliabel.

\subsection{Hasil Uji Asumsi Klasik}

\subsubsection{Uji Normalitas}

Uji normalitas merupakan prasyarat pokok dalam analisis parametrik seperti korelasi, uji perbandingan rata-rata, analisis varian dan sebagainya, karena data yang akan diuji parametric harus berdistribusi normal. Uji normalitas ini dilakukan untuk mengetahui apakah populasi data berdistribusi normal atau tidak. Dan dalam SPSS metode yang sering digunakan adalah uji one sample Kolmogorov Smirnov, dengan syarat data dikatakan berdistribusi normal jika nilai signifikansi $>0,05$ (Priyatno, 2011:77).

Adapun hasil uji normalitas pada penelitian ini yang diolah dengan SPSS ver. 21 adalah sebagai berikut. Berdasarkan tabel hasil uji normalitas menunjukkan bahwa nilai signifikansi (2-tailed) untuk semua variabel $>0,05$. Variabel sosial (X1) nilai sig (2-2tailed) 0,062, variabel ekonomi (X2) nilai sig (2-2tailed) 0,056 dan variabel lingkungan (X3) nilai sig (2-2tailed) 0,186. Dengan demikian dapat disimpulkan bahwa data yang digunakan dalam penelitian ini berdistribusi normal dan layak untuk digunakan.

\subsubsection{Uji Multikolinieritas}

Adapun hasil uji multikolinieritas pada penelitian ini adalah sebagai berikut. Berdasarkan tabel hasil uji multikolinieritas menunjukkan bahwa tidak terjadi multikolinieritas dimana nilai VIF masingmasing variabel dibawah 10 dan nilai toleransi mendekati 1 . 


\subsubsection{Uji Heterokedaskisitas}

Uji multikolinieritas digunakan untuk mengetahui apakah dalam model regresi terdapat korelasi antar variabel bebas. Model regresi yang baik seharusnya tidak terjadi korelasi antar varabel bebas tersebut. Untuk menguji hal ini dengan memperhatikan nilai korelasi yang dihasilkan serta nilai VIF (Variance Inflation Factor) dan Toleransinya. Apabila nilai VIF berada dibawah 10 dan nilai toleransi mendekati 1, maka diambil kesimpulan bahwa model regresi tersebut tidak terdapat multikolinieritas (Singgih Santoso, 2000). Berdasarkan hasil uji heterokedastisitas menujukkan bahwa nilai signifikansi untuk semua variabel >0,05 sehingga dapat disimpulkan bahwa tidak terjadi gejala heterokedastisitas dari ketiga variabel tersebut.

\subsection{Hasil Uji Hipotesis}

\subsubsection{Uji F (Uji Signifikan Simultan)}

Berdasarkan hasil uji F pada penelitian ini adalah sebesar 5149,91 dengan angka signifikansi $(P$ value) sebesar 0,000 . Dengan tingkat signifikansi $95 \%(\alpha=0,05)$. Angka signifikansi $(P$ value $)$ sebesar $0,000<0,05$. Berdasarkan perbandingan tersebut, maka $\mathrm{H}_{0}$ ditolak atau berarti variabel sosial, ekonomi, dan lingkungan mempunyai pengaruh yang signifikan secara bersama-sama terhadap variabel keberadaan jalan tol layang AP Pettarani.

\subsubsection{Uji t (Uji Signifikan Parametrik Individual)}

1. Hasil uji t pertama (variabel sosial)

Pada variabel sosial dengan tingkat signifikansi $95 \%(\alpha=0,05)$. Angka signifikansi $(P$ Value $)$ sebesar $0,000<0,05$, maka dapat disimpulkan bahwa $\mathrm{H}_{0}$ ditolak yang berarti variabel sosial secara parsial mempunyai pengaruh yang signifikan terhadap variabel keberadaan jalan tol layang AP Pettarani. 2. Hasil uji t kedua (variabel ekonomi)

Pada variabel ekonomi dengan tingkat signifikansi $95 \%(\alpha=0,05)$. Angka signifikansi $(P$ Value $)$ sebesar $0,000<0,05$, maka dapat disimpulkan bahwa $\mathrm{H}_{0}$ ditolak yang berarti variabel ekonomi secara parsial mempunyai pengaruh yang signifikan terhadap variabel keberadaan jalan tol layang AP Pettarani. 3. Hasil uji t ketiga (variabel lingkungan)

Pada variabel lingkungan dengan tingkat signifikansi $95 \%(\alpha=0,05)$. Angka signifikansi ( $P$ Value $)$ sebesar $0,000<0,05$, maka dapat disimpulkan bahwa $\mathrm{H}_{0}$ ditolak yang berarti variabel lingkungan secara parsial mempunyai pengaruh yang signifikan terhadap variabel keberadaan jalan tol layang AP Pettarani.

\subsubsection{Uji Koefisien Determinasi $\left(\mathrm{R}^{2}\right)$}

Berdasarkan tabel menunjukkan bahwa nilai koefisien determinasi $\left(\mathrm{R}^{2}\right)$ sebesar 0,992 atau 99,2\%. Hal ini dapat diartikan bahwa variabel independen (sosial, ekonomi dan lingkungan) dapat menjelaskan variabel dependen sebesar $99,2 \%$ sisanya $0,80 \%$ dijelaskan oleh variabel lain yang tidak diteliti.

\subsection{Analisis Regresi Linier Berganda}

Hasil regresi dengan menggunakan SPSS ver. 21 diperoleh koefisien regresi seperti pada tabel berikut. Berdasarkan tabel diperoleh persamaan regresi linier berganda sebagai berikut:

$$
Y=0,711+0,976 X_{1}+0,998 X_{2}+0,985 X_{3}
$$




\section{Coefficients $^{\mathbf{a}}$}

\begin{tabular}{|c|c|c|c|c|c|}
\hline \multirow[t]{2}{*}{ Model } & \multicolumn{2}{|c|}{$\begin{array}{c}\text { Unstandardized } \\
\text { Coefficients }\end{array}$} & \multirow{2}{*}{$\begin{array}{c}\text { Standardized } \\
\text { Coefficients } \\
\text { Beta }\end{array}$} & \multirow[t]{2}{*}{$\mathrm{t}$} & \multirow[t]{2}{*}{ Sig. } \\
\hline & B & Std. Error & & & \\
\hline (Constant) & .711 & .536 & & 1.326 & .187 \\
\hline $\mathrm{X} 1$ & .976 & .029 & .342 & 34.208 & .000 \\
\hline $\mathrm{X} 2$ & .998 & .028 & .391 & 35.451 & .000 \\
\hline $\mathrm{X} 3$ & .985 & .021 & .462 & 46.105 & .000 \\
\hline
\end{tabular}

Dijelaskan sebagai berikut:

1. Nilai koefisien konstanta bernilai positif dan jika segala sesuatu pada variabel - variabel bebas (Independent) dianggap konstan maka nilai keberadaan jalan Tol Layang AP. Pettarani adalah 0,711.

2. Nilai 0,976 pada variabel sosial $\left(X_{1}\right)$ adalah bernilai positif dan apabila nilai aspek sosial meningkat sebesar satu - satuan atau satu tingkat makan akan terjadi peningkatan terhadap keberadaan jalan tol Layang AP. Pettarani sebesar $(0,711+0,976=1,687)$ menjadi 1,687 dengan asumsi variabel yang lainnya tetap atau konstan $\left(\mathrm{X}_{2}+\mathrm{X}_{3}=0\right)$.

3. Nilai 0,998 pada variabel ekonomi $\left(\mathrm{X}_{2}\right)$ adalah bernilai positif dan apabila nilai aspek ekonomi meningkat sebesar satu - satuan atau satu tingkat makan akan terjadi peningkatan terhadap keberadaan jalan tol layang AP. Pettarani sebesar $(0,711+0,998=1,709)$ menjadi 1,709 dengan asumsi variabel yang lainnya tetap atau konstan $\left(\mathrm{X}_{1}+\mathrm{X}_{3}=0\right)$.

4. Nilai 0,985 pada variabel lingkungan $\left(X_{3}\right)$ adalah bernilai positif dan apabila nilai aspek lingkungan meningkat sebesar satu - satuan atau satu tingkat makan akan terjadi peningkatan terhadap keberadaan jalan tol layang AP. Pettarani sebesar $(0,711+0,985=1,696)$ menjadi 1,687 dengan asumsi variabel yang lainnya tetap atau konstan $\left(\mathrm{X}_{1}+\mathrm{X}_{2}=0\right)$.

\section{KESIMPULAN}

Persepsi perubahan pada aspek sosial mempunyai pengaruh signifikan dan bersifat positif terhadap keberadaan jalan tol layang AP Pettarani berdasarkan hasil statistik kualitatif yaitu aspek sosial memberi pengaruh sebesar 0,976, pengaruhnya terhadap keberadaan jalan tol layang AP Pettarani sebesar 26,6\% dan indikator yang paling besar pengaruhnya adalah X1.1 (Tingkat Stress). Persepsi perubahan pada aspek ekonomi mempunyai pengaruh yang signifikan dan bersifat positif terhadap keberadaan jalan tol layang AP Pettarani berdasarkan hasil statistik kualitatif yaitu aspek ekonomi memberi pengaruh sebesar 0,998, pengaruhnya terhadap keberadaan jalan tol layang AP Pettarani sebesar 33,6\% dan indikator yang paling besar pengaruhnya adalah X2.2 (Biaya BBM). Persepsi perubahan pada aspek lingkungan mempunyai pengaruh yang signifikan dan bersifat positif terhadap keberadaan jalan tol layang AP Pettarani berdasarkan hasil statistik kualitatif yaitu aspek lingkungan memberi pengaruh sebesar 0,985 , pengaruhnya terhadap keberadaan jalan tol layang AP Pettarani sebesar 33,6 \% dan indikator yang paling besar pengaruhnya adalah X3.2 (Tingkat Polusi Udara dari Asap Kendaraan).

\section{DAFTAR PUSTAKA}

Aulia, Meidianisa. 2016. Analisis Dampak Sosial Ekonomi Pengguna Jalan Akibat Kemacetan Lalu Lintas Di Banda Aceh. Aceh: Jurnal Ekonomi dan Kebijakan Publik. Vol.3, No.1:26-33.

Arrang, A. T. (2016). Tinjauan Keselamatan Lalu Lintas terhadap Geometrik Jalan Ruas Toraja-Palopo (Studi Kasus Sta. 379+ 170-Sta. 383+ 300). PENA TEKNIK: Jurnal Ilmiah Ilmu-Ilmu Teknik, 1(2), 149-154.

Boediningsih, W. 2011. Dampak Kepadatan Lalu Lintas Terhadap Polusi Udara Kota Surabaya. Jurnal, Fisu, A. A. (2019). Tinjauan Kecelakaan lalu Lintas Antar Wilayah Pada Jalan Trans Provinsi Sulawesi Selatan. PENA TEKNIK: Jurnal Ilmiah Ilmu-ilmu Teknik, 4(1), 53-65.

Hidayat, Rahmat, Diana Sapha. 2017. Dampak Kemacetan Terhadap Sosial Ekonomi Pengguna Jalan di Kota Banda Aceh. Banda Aceh: Jurnal Ilmiah Mahasiswa. Vol.2, No.1:176-186. 
Humang, W. P., \& Amrin, A. (2018). Peningkatan Akses Jalan Untuk Menunjang Distribusi Hasil Produksi Kota Terpadu Mandiri (Ktm) Air Terang Kabupaten Buol. Pena Teknik: Jurnal Ilmiah Ilmu-Ilmu Teknik, 1(2), 111-124.

Ismadarni. 2012. Pengaruh Aspek Sosial Ekonomi Masyarakat terhadap Bangkitan Pergerakan Zona Kemacetan di Kota Palu. Jurnal Rekayasa dan Manajemen Transportasi.

Pangaribuan, Gerhard P. 2005. Perhitungan Biaya Kemacetan pada Sekitar Wilayah Pengendalian Lalu Lintas. Program Pascasarjana. Fakultas Teknik. Universitas Indonesia.

Pangaribuan, Silvana Monica, 2014. Analisis Dampak Kemacetan Terhadap Sosial Ekonomi Pengguna Jalan di Kota Medan (Studi Kasus: Area Simpang Pos). Skripsi, Medan: Fakultas Ekonomi Universitas Sumatera Utara.

Pratiwi, Rizqa Hardini, 2016. Dampak Kemacetan terhadap Kondisi Sosial dan Ekonomi Pengguna Jalan di Jakarta Utara. Skripsi, Jakarta: Fakultas Ekonomi dan Bisnis Unpas Bandung.

Said. L.B, Maryam H, and Abdul H.H, 2017, Society's Behavior of Personal Transportation Utilization in Makassar South Sulawesi Indonesia, Scintific Academic Publishing, 7(3) p:131-137, P-ISSN : 2162-9374; e-ISSN : 2162-8416.

Said. L.B, A. Kadir S, A Alifuddin, 2017, A Mixture of Traffic Circle and Underpass to Increase Capacity of Intersection, Medwell Journals Scientific Research Publishing Company, Journal of Engineering and Applied Sciences, 12(8) p:8436-8440, ISSN : 1816-949X ; e-ISSN : 1818-7803.

Said. L.B, Ilham S, 2019, Integrated and Coordinated Traffic Management Based On Central Business District In Makassar City Indonesia, IAEME Publication, Scopus Indexed, pISSN 0976-6308 e-ISSN 09766316, International Journal of Civil Engineering and Technology (IJCIET) 10(01), pp. 2210-2223.

Sari, D. A., \& Kisman, A. (2021). Penilaian Kondisi Jalan Poros Sabbang Selatan Menggunakan Metode Surface Distress Index. PENA TEKNIK: Jurnal Ilmiah Ilmu-Ilmu Teknik, 6(1), 24-31.

Silondae, Sutami, Ernawati dan Abdul Azis Muthalib. 2016. Keterkaitan Jalur Transportasi dan Interaksi Ekonomi Kabupaten Konawe Utara dengan Kabupaten/Kota Sekitarnya. Kendari: Jurnal Progres Ekonomi Pembangunan. Vol.1, No.1:49-64.

Watono, W., Muin, S. A., CA, M. R., \& Firdaus, D. (2020). Analisa Biaya Penanganan Berdasarkan Penilaian Kondisi Jalan dengan Metode Road Condition Index (RCI) pada Ruas Jalan Hertasning. PENA TEKNIK: Jurnal Ilmiah Ilmu-Ilmu Teknik, 5(1), 11-18. 